\title{
Videoendoscopy for Treating Degenerative Disc Disease with Lumbar Canal Stenosis Techniques Portals and instrumentation A Systematic Review
}

\author{
Max Rogério Freitas Ramos ${ }^{1 *}$, Paulo Sérgio Teixeira de Carvalho ${ }^{2}$, Rossana Ribeiro de Melo \\ Ramos $^{3}$, Alexandre Peixoto ${ }^{4}$, Paulo de Carvalho ${ }^{5}$ and Mark de Melo Ramos ${ }^{6}$ \\ ${ }^{1}$ Associate Professor of Orthopedics and Traumatology, Federal University of the Rio de Janeiro State UNIRIO, Gaffrée Guinle \\ University Hospital HUGG, Brazil
}

${ }^{2}$ Professor of Neurosurgery at the Federal University of the State of Rio de Janeiro UNIRIO, Brazil

${ }^{3}$ Orthopaedic Pain Specialist by Federal University of the State of Rio de Janeiro UNIRIO, Brazil

${ }^{4}$ Adjunct Professor of Orthopedics and Traumatology, Federal University of the Rio de Janeiro State UNIRIO, Brazil

${ }^{5}$ Department of Neurosurgery at KRH Nordstadt Krankenhaus Hospital, Germany

${ }^{6}$ Medicine Student, Estadual University of The Rio de Janeiro UERJ, Brazil

*Corresponding author: Max Rogério Freitas Ramos, Associate Professor of Orthopedics and Traumatology, Federal University of the Rio de Janeiro State UNIRIO, Head of Orthopedic Clinics at Gaffrée Guinle University Hospital HUGG, Brazil

\begin{tabular}{|c|}
\hline ARTICLE INFO \\
\hline Received: 幽 August 09, 2020 \\
\hline Published: 蔧 August 19, 2020 \\
\hline
\end{tabular}

Citation: Max Rogério Freitas R, Paulo Sérgio Teixeira de C, Rossana Ribeiro de Melo $\mathrm{R}$, Alexandre $\mathrm{P}$, et al., Videoendoscopy for Treating Degenerative Disc Disease with Lumbar Canal Stenosis Techniques Portals and instrumentation A Systematic Review. Biomed J Sci \& Tech Res 29(4)-2020. BJSTR. MS.ID.004836.

\begin{abstract}
The main objective of this study was to present a systematic review covering the main indications, results and complications of video endoscopic surgery in the treatment of this associated diseases disc degeneration with lumbar canal stenosis. Studies show that the best form of treatment for this condition is a surgical decompression that has lately been associated with endoscopy video. The main objective of this study was to present a systematic review about the indications, results and complications of endoscopic video surgery in the treatment of lumbar degenerative disc disease with canal stenosis. A systematic review was adopted using the keywords "endoscopy" "disc disease" and "stenosis" interspersed by the boolean operator "AND". The databases selected for search were: PubMed, Scielo, LILACS and Cochrane plus manual research in gray literature. Studies published from 2000 in English, Portuguese and Spanish were included, and literature and systematic reviews were excluded. The results indicate that surgical decompression associated with endoscopic video foraminoplasty improves pain scores and reduces patient morbidity and increase the movement of the lower limbs.
\end{abstract}

Keywords: Lumbar Spinal Stenosis; Disc Disease; Endoscopy Video; Spine; Surgical Decompression

\section{Introduction}

Lumbar disc degenerative disease with canal stenosis is considered a disease resulting from aging because it affects the intervertebral discs through progressive degeneration and, at the same time, arthrosis of the posterior articular facets occurs, resulting in a narrowing of the spine [1]. According to Brandt et al [1], stenosis "can cause compression of one or more roots of the cauda equina", and "compression of the neural tissue can be 
localized, segmented or generalized, through bone, disc or ligament structures". Videoendoscopy for the treatment of isolated lumbar herniated discs is now common place with favorable clinical results comparable to microdiscectomy and a low rate of complication rate. The transforaminal approach is frequently applied to the endoscopic treatment of herniated discs mainly at the L3/L4, and L4/L5 level. The approach is also feasible at L5/S1 but may be technically more demanding because of the configuration of the iliac wing, sacralization of the L5 vertebral body, or because of degenerative vertical collapse of the spine. Placing the working cannula may be harder at this transitional level due to steeper attack angles making injury to the exiting L5 nerve root more likely. Regardless of the level, additional risks for nerve root injury due to increasing surgery time and more aggressive manipulation may arise if the surgeon is attempting to access a highly stenotic neuroforamen during the endoscopic decompression procedure.

The lumbar disc disease with canal stenosis may have a congenital, acquired origin or an association between the two forms. Congenital stenosis is the result of achondroplasty while acquired stenosis is associated with spondylolisthesis. Thus, with aging and degeneration, the intervertebral disc loses its viscoelastic characteristic, with the possibility of lacerations in the fibrous annulus, fragmentation of the pulpal nucleus and, consequently, loss of disc height "[1]. Conventional treatment includes local decompression of the lumbar region with hemilaminectomy or laminectomy, with a view to releasing the vertebral foramina. The insertion of video endoscopy has brought many benefits for the treatment of lumbar canal stenosis in this aspect, such as greater accuracy and sensitivity at the time of surgical access and manipulation [2], but because it is a relatively new and still littleused treatment method, in addition to of needing specialized training with a specific learning curve more than de simple videoendoscopic discectomies, even today it raises questions about its indication, results and complications. In view of these considerations, the main objective of this study was to present a systematic review covering the main indications, results and complications of video endoscopic surgery in the treatment of this associated diseases disc degeneration with lumbar canal stenosis.

\section{Material and Methods}

First, the guiding question of this research was established: "What are the indications, results and complications of video endoscopic surgery in the treatment of disc degeneration with lumbar canal stenosis?" On this basis, a search was made for the most appropriate terms for establishing the research strategy in the Medical Subject Headings (MeSH), having been chosen the terms "endoscopy" and "stenosis" interspersed by the Boolean operator "AND". The databases selected for search were: PubMed, Scielo, LILACS and Cochrane plus manual research in the gray literature (Google Scholar and studies published in congresses and scientific events).

\section{Inclusion and Exclusion Criteria}

This research included studies from the year 2000, being clinical or experimental trials conducted in vitro and in vivo regarding video endoscopic surgery for the treatment of disc degeneration with lumbar canal stenosis.

Studies prior to 2000 systematic reviews, literature reviews, editorials, book chapters and encyclopedias were excluded. The summary table containing the inclusion and exclusion criteria is shown below in Chart 1 .

Chart 1: Inclusion and Exclusion Criteria.

\begin{tabular}{|c|c|}
\hline Inclusion & Exclusion \\
\hline Articles, theses, dissertations and monographs available in full & Works that are not available in full \\
\hline Works in English, Portuguese and Spanish & Works in other languages \\
\hline Case Reports, Randomized controlled clinical trials. & Letters to the editor, editorials, reports, literature reviews, interviews \\
\hline Works published since 2000 & Works prior to the year 2000 \\
\hline
\end{tabular}

\section{Results}

Once the search strategy and inclusion and exclusion criteria were established, 4,982 studies were initially found in PubMed, 191 in LILACS, 278 in Cochrane and 96 in Scielo, totaling 5,547 studies. After removing duplicates by reference management software, 434 studies remained. The manual search in the gray literature (Google Scholar), after applying inclusion and exclusion criteria, resulted in 26 studies. Then, the titles of the works initially selected were read and 2,065 studies were removed because they did not fit the scope of this research. Sequentially, after reading the abstracts, 67 more papers were removed that did not meet the inclusion and exclusion criteria of this study. Thus, 48 potentially eligible jobs remained. In the manual search of the references present in the potentially eligible studies, 2 works of interest and possibly of applicability in this research were verified, that is, after searching a list of 457 references. However, these 2 studies were removed after reading the summary because they did not meet the inclusion and exclusion criteria. However, after a complete reading of the 14 potentially eligible articles, 6 were excluded due to lack of qualification in this research. 
However, after the selection process, 12 articles were listed for qualitative analysis. The selection process is summarized in the flowchart in Figure 1. Below, the 12 papers selected for the review are presented in Table 1, subdivided into: Author, Year, Type of study, Sample, Results and Considerations [3-14].

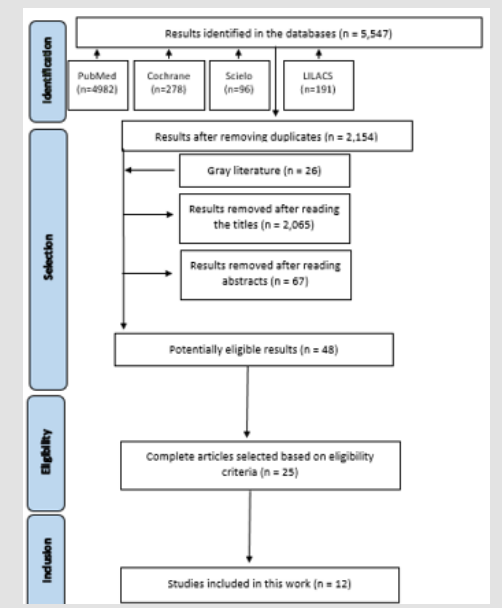

Figure 1: Flowchart of the article selection process based on the PRISMA protocol.

Table 1: Results of the Revision.

\begin{tabular}{|c|c|c|c|c|c|}
\hline Author & Year & kind of study & Sample & Results & Considerations \\
\hline Nomura et al. [3] & 2014 & Clinical trial & $\begin{array}{l}70 \text { patients totaling } \\
126 \text { levels of stenosis }\end{array}$ & $\begin{array}{l}\text { The average time per } \\
\text { operation was } 77 \\
\text { minutes with a loss of } \\
15 \mathrm{~mL} \text { of blood. There } \\
\text { was no epidural injury } \\
\text { or neurological deficit }\end{array}$ & $\begin{array}{l}\text { Microsurgery with } \\
\text { video endoscopy } \\
\text { improves surgical } \\
\text { precision resulting in } \\
\text { better prognosis. }\end{array}$ \\
\hline Yagi et al. [4] & 2009 & $\begin{array}{l}\text { Randomized clinical } \\
\text { trial }\end{array}$ & $\begin{array}{l}41 \text { patients with } \\
\text { lumbar stenosis, } \\
21 \text { for conventional } \\
\text { laminectomy and } 20 \\
\text { for microendoscopic } \\
\text { laminectomy }\end{array}$ & $\begin{array}{l}\text { Patients who received } \\
\text { microendosco-sink } \\
\text { surgery }\end{array}$ & $\begin{array}{l}\text { Although } \\
\text { microendoscopy } \\
\text { decompression } \\
\text { requires more uptime } \\
\text { than a conventional } \\
\text { method, it requires } \\
\text { only minimal } \\
\text { muscle trauma and } \\
\text { maintenance of spinal } \\
\text { stability, in addition } \\
\text { to allowing early } \\
\text { mobilization. This } \\
\text { reduces the hospital } \\
\text { stay. }\end{array}$ \\
\hline & & & & $\begin{array}{l}\text { had a reduced average } \\
\text { length of hospital } \\
\text { stay, a lower mean } \\
\text { level of muscle-type } \\
\text { isoenzyme creatine } \\
\text { phosphokinase, a } \\
\text { lower visual analog } \\
\text { scale score for back } \\
\text { pain at } 1 \text { year and a } \\
\text { faster recovery rate. }\end{array}$ & \\
\hline
\end{tabular}




\begin{tabular}{|c|c|c|c|c|c|}
\hline Eum et al. [5] & 2016 & Case Series & $\begin{array}{l}58 \text { patients with } \\
\text { single-level lumbar } \\
\text { stenosis. Biportal } \\
\text { access being an } \\
\text { access for irrigation } \\
\text { and video endoscopy } \\
\text { and another for } \\
\text { instrumentalization } \\
\text { and microsurgery }\end{array}$ & $\begin{array}{l}81 \% \text { of patients } \\
\text { showed excellent } \\
\text { recovery and reduced } \\
\text { visual analogue pain } \\
\text { scale. }\end{array}$ & $\begin{array}{l}\text { The reported } \\
\text { procedure is } \\
\text { minimally invasive } \\
\text { and percutaneous } \\
\text { biportal endoscopy } \\
\text { is very similar to } \\
\text { microscopic spinal } \\
\text { surgery, allowing a } \\
\text { good visualization } \\
\text { of the contralateral } \\
\text { and medial foraminal } \\
\text { sublaminar areas. }\end{array}$ \\
\hline & & & & $\begin{array}{l}\text { Decompression was } \\
\text { successful in } 100 \% \text { of } \\
\text { cases. }\end{array}$ & \\
\hline Kim et al. [6] & 2016 & Case Series & $\begin{array}{l}48 \text { patients with } \\
\text { lumbar stenosis } \\
\text { treated by uniportal } \\
\text { means associated with } \\
\text { decompression with } \\
\text { microendoscopy }\end{array}$ & $\begin{array}{l}\text { The visual analog scale } \\
\text { showed a significant } \\
\text { reduction, and } \\
\text { decompression was } \\
\text { effective in most cases } \\
\text { (96\% of patients). Only } \\
6 \% \text { of patients had } \\
\text { dural rupture. }\end{array}$ & $\begin{array}{l}\text { This study is } \\
\text { considered } \\
\text { preliminary and } \\
\text { showed a good } \\
\text { improvement in terms } \\
\text { of decompression. } \\
\text { However, the authors } \\
\text { suggest more rigorous } \\
\text { and long-term analyzes } \\
\text { to verify effectiveness } \\
\text { and safety. }\end{array}$ \\
\hline Khoo et al. [7] & 2002 & $\begin{array}{l}\text { Randomized clinical } \\
\text { trial }\end{array}$ & $\begin{array}{l}50 \text { elderly patients, } 25 \\
\text { for microendoscopy } \\
\text { access and } 25 \text { for open } \\
\text { field decompression }\end{array}$ & $\begin{array}{c}\text { Effective } \\
\text { circumferential } \\
\text { decompression was } \\
\text { achieved in most } \\
\text { patients. The results } \\
\text { for the MEDL group } \\
\text { were as follows: } \\
\text { operating time, 109 } \\
\text { minutes per single } \\
\text { level; blood loss, } 68 \\
\text { ml; and postoperative, } \\
\text { 42 hours. The } \\
\text { results for the open } \\
\text { surgery group were } \\
\text { as follows: surgical } \\
\text { time, } 88 \text { minutes; } \\
\text { blood loss, } 193 \text { ml; } \\
\text { and postoperative } \\
\text { stay, } 94 \text { hours. The } \\
\text { MEDL group needed } \\
\text { fewer narcotic } \\
\text { drugs after surgery. } \\
\text { Overall, } 16 \% \text { of SCI } \\
\text { patients reported } \\
\text { resolution of back } \\
\text { pain, } 68 \% \text { improved } \\
\text { symptomatically } \\
\text { and } 16 \% \text { remained } \\
\text { unchanged. The result } \\
\text { of the open group was } \\
\text { very similar. }\end{array}$ & $\begin{array}{c}\text { Microendoscopic } \\
\text { decompression } \\
\text { appears to offer a } \\
\text { similar short-term } \\
\text { clinical result, with a } \\
\text { significant reduction } \\
\text { in operative blood loss, } \\
\text { postoperative stay and } \\
\text { use of medications. } \\
\text { This lesser surgical } \\
\text { stress, decreased } \\
\text { tissue trauma and } \\
\text { faster recovery are } \\
\text { particularly important } \\
\text { in this elderly patient } \\
\text { population. }\end{array}$ \\
\hline Heo et al. [8] & 2018 & Case Control & $\begin{array}{l}88 \text { patients with } \\
\text { lumbar stenosis, } 48 \\
\text { for percutaneous } \\
\text { biportal video } \\
\text { endoscopy surgery and } \\
40 \text { for conventional } \\
\text { microscopy surgery }\end{array}$ & $\begin{array}{l}\text { There was a more } \\
\text { effective reduction } \\
\text { in pain in the group } \\
\text { treated with video } \\
\text { endoscopy compared } \\
\text { to the microscopy } \\
\text { group. The visual } \\
\text { analog scale showed } \\
\text { a reduction in both } \\
\text { groups. }\end{array}$ & $\begin{array}{l}\text { The percutaneous } \\
\text { biportal } \\
\text { decompression } \\
\text { approach with } \\
\text { endoscopy is safe } \\
\text { and effective in the } \\
\text { treatment of lumbar } \\
\text { stenosis. }\end{array}$ \\
\hline
\end{tabular}




\begin{tabular}{|c|c|c|c|c|c|}
\hline Heo et al. [9] & 2019 & Clinical trial & $\begin{array}{l}33 \text { patients for } \\
\text { microscopic surgery, } \\
37 \text { for biportal } \\
\text { endoscopy and } 27 \text { for } \\
\text { uniportal endoscopy }\end{array}$ & $\begin{array}{c}\text { The uniportal } \\
\text { endoscopy technique } \\
\text { was less successful } \\
\text { than microscopy and } \\
\text { biportal access, in a } \\
\text { statistically significant } \\
\text { way. As for the Visual } \\
\text { Analogue Scale, the } \\
\text { value was higher in } \\
\text { patients operated with } \\
\text { microscopy. }\end{array}$ & $\begin{array}{c}\text { Postoperative } \\
\text { clinical conditions } \\
\text { were significantly } \\
\text { improved after each } \\
\text { type of surgery. } \\
\text { The percutaneous } \\
\text { biportal or uniportal } \\
\text { endoscopic approach } \\
\text { offers the advantage } \\
\text { of reducing immediate } \\
\text { postoperative pain. }\end{array}$ \\
\hline & & & & & $\begin{array}{l}\text { The lumbar approach } \\
\text { can be effective in the } \\
\text { treatment of central } \\
\text { lumbar stenosis } \\
\text { and an alternative } \\
\text { to conventional } \\
\text { microsurgical } \\
\text { decompression }\end{array}$ \\
\hline Li et al. [10] & 2016 & $\begin{array}{l}\text { Randomized clinical } \\
\text { trial }\end{array}$ & $\begin{array}{l}182 \text { cases of patients } \\
\text { with lumbar stenosis } \\
\text { analyzed two years } \\
\text { after the operation } \\
\text { using endoscopy } \\
\text { associated with } \\
\text { foraminoplasty }\end{array}$ & $\begin{array}{l}95 \text { cases were } \\
\text { successful in surgical } \\
\text { decompression. Pain, } \\
\text { assessed on the Visual } \\
\text { Analogue Scale, was } \\
\text { significantly reduced } \\
\text { after the procedure }\end{array}$ & $\begin{array}{l}\text { The foraminoplasty } \\
\text { procedure is specially } \\
\text { designed to be a less } \\
\text { invasive, effective } \\
\text { and safe surgery for } \\
\text { stenosis of the lumbar } \\
\text { lateral recess with / } \\
\text { without combined HD. }\end{array}$ \\
\hline Knight et al. [11] & 2014 & & $\begin{array}{c}112 \text { patients with } \\
\text { lumbar stenosis } \\
\text { treated with } \\
\text { transforaminal } \\
\text { endoscopy associated } \\
\text { with foraminoplasty, } \\
\text { analyzed } 10 \text { years after } \\
\text { the surgical procedure. }\end{array}$ & $\begin{array}{c}\text { Pain scores } \\
\text { significantly decreased, } \\
\text { and decompression } \\
\text { was successful in } \\
\text { more than half of the } \\
\text { patients analyzed. }\end{array}$ & $\begin{array}{l}\text { Treatment is effective } \\
\text { for decompression of } \\
\text { lumbar stenosis. }\end{array}$ \\
\hline Kim et al [12] & 2011 & Case series & $\begin{array}{c}5 \text { patients with } \\
\text { lumbar canal stenosis } \\
\text { operated with video } \\
\text { endoscopy through } \\
\text { contralateral access } \\
\text { and foraminoplasty }\end{array}$ & $\begin{array}{l}\text { Pain scores showed a } \\
\text { significant reduction } \\
\text { and decompression } \\
\text { was successful in all } \\
\text { cases. }\end{array}$ & $\begin{array}{l}\text { The success of the } \\
\text { PELD procedure } \\
\text { depends on the proper } \\
\text { placement of the } \\
\text { work instruments. An } \\
\text { inappropriate path } \\
\text { for pathology is one } \\
\text { of the main causes } \\
\text { of the failure of this } \\
\text { procedure. }\end{array}$ \\
\hline Palmer et al. [13] & 2012 & Clinical trsial & $\begin{array}{l}17 \text { patients with } \\
\text { lumbar canal stenosis } \\
\text { treated by bilateral } \\
\text { decompression } \\
\text { surgery }\end{array}$ & $\begin{array}{l}\text { There was successful } \\
\text { decompression in most } \\
\text { cases and a reduction } \\
\text { in pain scores, with a } \\
\text { low morbidity rate }\end{array}$ & $\begin{array}{c}\text { Minimally } \\
\text { invasive bilateral } \\
\text { decompression and } \\
\text { instrumentation- } \\
\text { assisted fusion can be } \\
\text { successfully performed } \\
\text { unilaterally in } \\
\text { patients with acquired } \\
\text { spinal stenosis; the } \\
\text { procedure can be } \\
\text { performed on an } \\
\text { outpatient basis with } \\
\text { reasonable surgical } \\
\text { time, minimal blood } \\
\text { loss and acceptable } \\
\text { morbidity rates }\end{array}$ \\
\hline
\end{tabular}




\begin{tabular}{|c|c|c|c|c|c|}
\hline & & & & $\begin{array}{c}\text { Transforaminal } \\
\text { endoscopic } \\
\text { decompression under } \\
\text { local anesthesia } \\
\text { can be an effective } \\
\text { treatment method for } \\
\text { the selected group of } \\
\text { patients with spinal } \\
\text { stenosis }\end{array}$ \\
\hline
\end{tabular}

\section{Discussion}

Lumbar disc degenerative with canal stenosis as known can occur as part of a generalized disease process and involves several areas of the canal and several levels or, conversely, can be located or segmented [15], all the studies analyzed demonstrate the importance of the surgical approach in cases refractory to conservative and physiotherapy treatment as the only alternative for satisfactory clinical improvement. One of the most common problems after transforaminal endoscopic decompression is dysesthesia due to compression of the dorsal root ganglion by the working cannula and its manipulation during its initial placement and the discectomy procedure and because of this, most authors prefer an interlaminar approach to start decompress of the stenosis by drilling facets and laminae and in sequence open the flavor ligament and proceed the discectomy.

The main signs and symptoms include painful radiculopathy associated with neurological deficits that can significantly affect the movement of lower limbs on the affected side. The introduction of corticosteroids in the subdural space has been described, but the results are inconstant and of short duration, and in the case of its ineffectiveness, the surgical procedure is also adopted [16]. According to the studies presented, lumbar decompression is the main form of treatment for this condition. The technique has been improved over the years and the addition of video endoscopy as an aid to visualize the exact lesion site [10].

The camera can be inserted via uniportal or biportal access. In the uniportal access, the instruments for manipulation and the camera are inserted in the same place, whereas, in the biportal access, the instruments are placed by one access and the camera by another [17]. Kim et al [6] considered the uniportal access adequate and sufficient for decompression of lumbar stenosis, however they emphasize that this study is considered preliminary and despite having presented a good improvement regarding decompression, they suggest more rigorous and long-term analyzes to verify efficacy and safety. Eum et al. [5] on the other hand, prefer percutaneous biportal endoscopy because they consider it very similar to microscopic spinal surgery, allowing a good visualization of the contralateral sublaminar and medial foraminal areas, they believe that it is a more appropriate approach in cases of severe compression, which was reinforced by Heo et al [9] who considered safe and effective treatment, with great advantages over open treatment.

Finally, Shin et al [14] emphasize that transforaminal endoscopic decompression can be performed on an outpatient basis under local anesthesia and that it can be an effective and low-cost treatment method for the selected group of patients with lumbar canal stenosis.

\section{Conclusion}

Video endoscopic surgical decompression improves pain and functional disability scores in lumbar degenerative disc with canal stenosis, is a safe technique, allows proper decompression of the canal and should be incorporated into the technical arsenal of the spine surgeon.

\section{References}

1. Brandt R A, Wajchenberg M (2008) Stenose of the cervical and lombar vertebral canal. Einstein 6: S29-32.

2. Alvarenga M A M, Vargas A A R, De Lima, M S X, Kaleff P R (2014) Description of the minimally invasive surgical technique totally endoscopic interlaminar video for the treatment of a lombar disc herniation. Brazilian Neurosurgery 33(3): 202-206.

3. Nomura K, Yoshida M (2012) Microendoscopic decompression surgery for lumbar spinal canal stenosis via the paramedian approach: preliminary results. Global Spine J 2(2): 87-94.

4. Yagi M, Eijiro Okada, Ken Ninomiya, Michiya Kihara (2009) Postoperative outcome after modified unilateral-approach microendoscopic midline decompression for degenerative spinal stenosis. Journal of neurosurgery. Spine 10(4): 293-299.

5. Eum J H, Heo D H, Son S K, Park C K (2016) Percutaneous biportal endoscopic decompression for lumbar spinal stenosis: a technical note and preliminary clinical results. Journal of Neurosurgery Spine 24(4): 602-607.

6. Kim H S, Paudel B, Jang J S, Oh S H, Lee S, et al. (2017) Percutaneous full endoscopic bilateral lumbar decompression of spinal stenosis through uniportal-contralateral approach: techniques and preliminary results. World neurosurgery 103: 201-209.

7. Khoo L T, Fessler R G (2002) Microendoscopic decompressive laminotomy for the treatment of lumbar stenosis. Neurosurgery 51: 146-154.

8. Heo D H, Quillo Olvera, J Park C K (2018) Can Percutaneous Biportal Endoscopic Surgery Achieve Enough Canal Decompression for Degenerative Lumbar Stenosis? Prospective Case-Control Study. World neurosurgery 120: e684-e689.

9. Heo D H, Lee D C, Park C K (2019) Comparative analysis of three types of minimally invasive decompressive surgery for lumbar central 
stenosis: biportal endoscopy, uniportal endoscopy, and microsurgery. Neurosurgical focus 46(5): E9.

10. Ahn Y (2014) Percutaneous endoscopic decompression for lumbar spinal stenosis. Expert Review of Medical Devices 11(6): 605-616.

11. Knight M T, Jago I, Norris C, Midwinter L, Boynes C (2014) Transforaminal endoscopic lumbar decompression \& foraminoplasty: a 10year prospective survivability outcome study of the treatment of foraminal stenosis and failed back surgery. International journal of spine surgery

12. Kim J S, Choi G, Lee S H (2011) Percutaneous endoscopic lumbar discectomy via contralateral approach: a technical case report. Spine 36(17): E1173-E1178

13. Palmer S, Turner R, Palmer R (2012) Bilateral decompression of lumbar spinal stenosis involving a unilateral approach with microscope and tubular retractor system. Journal of Neurosurgery: Spine 97(2): 213217.

\section{ISSN: 2574-1241}

DOI: $10.26717 /$ BJSTR.2020.29.004836

Max Rogério Freitas Ramos. Biomed J Sci \& Tech Res

(C) This work is licensed under Creative

Submission Link: https://biomedres.us/submit-manuscript.php
14. Shin S H, Bae J S, Lee S H, Keum H J, Kim H J, et al. (2018) Transforaminal endoscopic decompression for lumbar spinal stenosis: A novel surgical technique and clinical outcomes. World neurosurgery 114: e873-e882.

15. Arbit E, Pannullo S (2001) Lumbar stenosis: a clinical review. Clinical Orthopaedics 384: 137-143.

16. Farshad M, Sutter R, Hoch A (2018) Severity of foraminal lumbar stenosis and the relation to clinical symptoms and response to peri radicular infiltration-introduction of the "melting sign". The Spine Journal 18(2): 294-299.

17. Ulrich N H, Burgstaller J M, Held U, Winklhofer S, Farshad M, et al. (2017) The Influence of Single-Level vs Multilevel Decompression on the Outcome in Multisegmental Lumbar Spinal Stenosis: Analysis of the Lumbar Spinal Outcome Study (LSOS) Data-A Swiss Prospective Multicenter Cohort Study. The Spine Journal, 17(10): S164.

BIOMEDICAL
RESEARCHES $\quad$\begin{tabular}{l} 
Assets of Publishing with us \\
\hline Global archiving of articles
\end{tabular}

